\title{
Archaeology of Two Pandemics and Teranga Aesthetic
}

\author{
Ibrahima Thiaw
}

Published online: 25 August 2020

(C) Springer Science+Business Media, LLC, part of Springer Nature 2020

\begin{abstract}
The COVID-19 pandemic has exposed how coloniality and racism are endemic to modern society. This was reflected in many early western discourses, French in particular, about the pandemic in Africa. These discourses unveiled old colonial antagonism, projection, stigmatization, and paternalism. The articulation of such discourses among well-informed and sometimes well-meaning people calls for deeper introspection on archaeological practices and modalities of community engagement. Building on archaeology's multiple contributions to Africa's past and observed practices of resilience in Senegal by ordinary people in the face of the spread of COVID-19, this essay reflects on the relevance of the archives, including the archaeological record, as usable resources for managing the problems of our times.
\end{abstract}

Résumé La pandémie du covid-19 a révélé à quel point la colonialité et le racisme sont endémiques dans la société moderne. Au début de la pandémie, cela s'est reflété dans de nombreux discours occidentaux sur l'Afrique, notamment en France, lesquels ont dévoilé de vieux antagonismes coloniaux, des projections, des stigmatisations et du paternalisme. L'articulation de tels discours, même chez des personnes bien informées et parfois bien intentionnées, appelle à une introspection et

I. Thiaw $(\bowtie)$

Unité de Recherche en Ingénierie culturelle et en Anthropologie (URICA), Laboratoire d'Archéologie, IFAN-Université Cheikh

A. Diop, 206 Dakar, BP, Senegal

e-mail: ibrahima.thiaw@ucad.edu.sn à une réflectivité plus profondes sur les pratiques archéologiques et les modalités de l'engagement communautaire. S'appuyant sur les multiples contributions de l'archéologie pour la connaissance du passé de l'Afrique et sur les pratiques de résilience observées au Sénégal par les individus ordinaires face à la propagation du covid-19, cet essai pose la question de la pertinence des archives, notamment archéologiques, comme ressources utilisables dans la gouvernance des problèmes de notre temps.

Keywords COVID-19 · Coloniality · Racism · Archaeology $\cdot$ Senegal $\cdot$ Teranga aesthetic

\section{Introduction}

Our contemporary moment is plagued by two major pandemics: COVID-19 on the one hand and racism and coloniality on the other. In this reflection on the present moment, I seek to exhume the way in which certain discourses on COVID-19 attest to the interconnections between these two pandemics in the Senegalese context. First, I start the essay with the western discourses on the novel coronavirus pandemic in Africa. The strong colonial and racist foundations of those discourses call for an equally robust deconstruction but also for archaeological interventions to reassert Africa's pivotal role in all historical processes of human development. Then, I comment on how the performative responses of the Senegalese state to the COVID-19 pandemic were framed by the French colonial legacies. 
Second, I reflect briefly on the kinds of reflexivity that archaeologists should develop when dealing with crises such as COVID-19 in the communities where they work. Finally, in the third part, I share the resilience strategies mobilized by Senegalese society against COVID-19. These strategies are structured by the principles of teranga aesthetic's sociability, and they yield critical insights on how to perceive and understand disasters in archaeological contexts.

\section{Archaeology of Discourses on the Pandemic}

The announcement of the first person tested and declared positive for COVID-19 on Senegalese soil occurred on March 2, 2020. Ironically, that "Patient 0," as to follow the nomenclature of Senegalese Health and Social Action Ministry, was a Frenchman who had just returned from a visit to France. That appearance of coronavirus disease in Senegal sparked fear that reignited colonial trauma in the popular imagination. On March 4, the Senegalese daily L'Évidence titled its front page "France is coronizing Senegal" with the subtitle that posed this question: "Slave trade, economic colonization, epidemiological colonization?" (Maillard 2020).

On March 23, Senegalese President, Macky Sall, announced two types of measures, the "barrack measures" (prohibitions, restrictions, repressions) on the one hand and the "belly measures" (distribution of rice, oil, sugar, and soap) on the other (Sall 2020). To parody Foucault (1975), these "nourish and punish" measures suggestively recalled the "stick and carrot" policy of the French colonial government. Between the appearance of "Patient 0 " and the presidential address, the government took a series of measures, including the closure of schools, universities, and places of worship. During those two weeks, however, there were very few new COVID-19 cases and zero deaths. Yet, both the martial rhetoric, "we are at war," and the public staging involved, curiously recalled French President Emmanuel Macron's speeches on COVID-19.

The Eurocentric and mimetic nature of these measures gave rise to sharp public criticism. The criticism intensified when public opinion decried the exclusivity granted to Institut Pasteur, a private French biomedical research facility in Dakar, during the first fortnight of the pandemic to carry out virological tests at the expense of university laboratories and private practices owned by
Senegalese nationals. Although Institut Pasteur's monopoly was later broken, thanks to public opinion's pressure and perhaps due to a growing number of cases, the debate on neocolonialism picked up more strongly a few days later. Particularly at stake in these debates was the issue of the sovereignty of the Senegalese postcolonial state whose management of the pandemic and practices of authority appeared to be carbon copies of those of the former European imperial power, France.

On April 1, French medical doctors, Jean Paul Mira, head of the intensive care unit at the Cochin Hospital in Paris, and Camille Locht, research director at the Inserm (Institut national de la santé et de la recherche médicale ([National Institute for Health and Medical Research]), recommended on a French television channel (LCI) that a Bacille Calmette-Guérin (BCG) vaccine against the coronavirus be tested on Africans. In the controversial exchange, Mira told Locht: "If I can be provocative, shouldn't this study be done in Africa, where there are no masks, no treatment, no intensive care, a bit like it is done elsewhere on certain studies like AIDS, or on prostitutes: we try things because we know they are highly exposed. What do you think?" And Locht replied: "You are right, by the way. We are thinking in parallel to a study in Africa with the same type of approach, that does not prevent us from thinking in parallel to a study in Europe and Australia" (France 24 2020a, b). The racial contempt for Africans and questionable comparisons that proposed the use of Africans as guinea pigs in medical research during that television exchange brought back painful memories of colonial medical practice and gave rise to incredible but justified anger both in the social and in traditional media.

A few days before the Mira-Locht exchange, there had been an ecstatic reaction to the March 27 prediction of Antonio Guterres, the United Nations General Secretary, on France 24 television channel and Radio France International (RFI), that "even if the population [in Africa] is younger than in developed countries, there will be necessarily millions of deaths" on the continent due to the COVID-19 pandemic (France 24 2020a, b). Likewise, a memorandum from the French Ministry of Foreign Affairs, dated March 24, and titled "The Pangolin Effect: The Storm Heading to Africa" also forecasted a COVID-19 apocalypse in the continent (Mantelin 2020). It predicted that the national health systems of African states will be declared "automatically saturated" and that African countries will not be able to protect their populations. So far, as I write this essay 
four months later, these predictions have not come to fruition.

These representations and imaginations of Africa by "highly educated" French medical doctors, EuroAmerican scientists, and political experts, and by a top United Nations diplomat, did not take place in a vacuum. Rather, they are reflective of the dominant public opinion about Africa in the West, informed by colonial fantasy and fetishization. In these imaginations and representations of Africa, it is striking that the continent is still conflated with images of a land peopled by lesser human beings without problem-solving capacity. In this Eurocentric pathology, African bodies are only good for laboratory testing and experiments to satisfy western curiosity and anxieties about the pandemic. We should worry about these enduring colonial legacies that continue to undermine the significance of decades of archaeological efforts that conclusively assert Africa's strong contributions to all processes of human development, including the emergence of complex sociopolitical formations, food production, technological innovations, urban development, and much more.

To me, the relevant questions for the present moment are: What can we learn from Africa's resilience and long history of coping with pandemics? How can we harness Africa's deep time experiences in handling human disasters and make it usable in the governance of COVID19? These questions are contrary to the paternalist and alarmist calls that inundated the media and projected the colonial mindset of the aforementioned interlocutors about Africa. The fact that similar perspectives were aired on the Society of Africanist Archaeologists Listserv by well-meaning colleagues raised even more troubling questions. How do our political subjectivities shape our positionality? Is archaeological knowledge about Africa sufficiently accessible to diverse and global audiences, or is it still largely produced and consumed within the inner circle of professional archaeologists who brag about their finds and only thrive for career promotion? What kind of alternative archaeological practices, engagements, and interventions can these debates on COVID-19 pandemic inspire?

\section{Archaeology and Engagement}

What can archaeologists bring to the ongoing debates on COVID-19 pandemic, especially when it hits the communities we work with and to whom we have a strong attachment? I contend that the role of archaeologists in such contexts would be to deal with their own political subjectivities honestly. This would require selfreflection on the discourses and practices rooted in racism and coloniality and engage with communities not as experts but rather as students, listeners, and activists ready to lend our voices to fight paternalism and unsubstantiated projections on Africa. The assumption that a global pandemic must be worse in Africa relative to the global north implies the thought, even by wellmeaning people, that the continent has neither past nor present problem-solving capacity and initiative. This colonial mindset relegates Africans to a state of animality and denies them their humanity, a contradiction of the teachings of African archaeology in the past few decades. One would be saved from this erroneous thought by paying attention to the archives of the past, including the archaeological record, and to the resilient strategies of the moment which are rooted in the needs and demands of African communities, our "ethical clients" (Blakey and Rankin-Hill 2009). Tapping into material, documentary, and memory archives can enrich our understanding of the present and the self-awareness of the communities with whom we work. This must, however, be done with a sense of care, responsibility, and caution because there is a lot of pain embedded in those archives.

\section{Teranga Aesthetic and Resilience}

The catastrophic narratives in the initial western discourses as they relate to the COVID-19 pandemic in Africa had parallels in the wretched attitudes and the mimicry of some African leaders' rhetorical and performative responses to the crisis. However, on the ground in many parts of Africa, and Senegal in particular, the strategies leveraged by the general populations have been different from the racialized attitudes of the Global North. The management of the pandemic by the larger Senegalese society revealed a resilience inspired by deep-time lived experiences and memories.

Although local populations generally followed the directives of the health authorities, they vehemently resorted to their culture, heritage, and religion to cope with the pandemic. They manufactured their own masks, especially when the western supply chains were broken; resorted to traditional therapy en masse; and gathered together to say prayers in ways that were 
inspired by the ancestral practices of coping, especially when the social body was threatened by illness and other crises. They resuscitated mythical figures, particularly in areas where the national police was not available to enforce restrictions on social gatherings.

Different communities also observed various forms of teranga aesthetic, a Senegalese social value of "good hospitality" and sociability. In its mundane expression, teranga aesthetic prescribes treating guests with open arms (Riley 2016). In deeper meaning, it acts as a catharsis for vivre ensemble or living together by creating a space where solidarity and mutual aid, exchanges and donations, gender bonding, communal sovereignty, political and religious alliances, sharing and circulation of information, and much more are deployed. It structures the social, cultural, and linguistic landscape with its vocabularies, gestures, and habitus and reinforces social solidarity in the face of crisis and uncertainty. Teranga aesthetic offers us possibilities for reading archaeological contexts that may relate to social stress and disasters, including pandemics. Such contexts may have unique signatures of artifact assemblages, settlement patterns, material circulations, and cultural interactions.

Over the past few decades, archaeologists of the Senegambia have been struggling to explain the rapid development of numerous short-term archaeological sites spanning 20-50 years on average, particularly after 1500 (Canos-Donay 2016; Gueye 1998; Richard 2019; Thiaw 2012, 1999; Thilmans and Ravisé 1980). This pattern of nucleated small-scale, short-term settlements often 100-300 m distant from one another has been identified with the growing insecurity during the Atlantic slave trade. However, recent experience is suggestive that this settlement pattern may be related to human disasters, including epidemics (Altschul et al. 2016; Thiaw et al. 2018). A case in point is the bubonic plague that hit Dakar from April 1914 to January 1915, killing 3653 people out of a population of 26,000 inhabitants in less than a year. The French colonial government took a series of harsh decisions including the displacement and confinement of African populations in new neighborhoods, the imposition of new architectural standards with bricks and stones, the burning of huts and quarantine camps, issuance of movement passes for Africans, and the establishment of sanitary cordons, among many other measures (Bigon 2012). In reaction to these, many Africans moved to the outskirt of Dakar, where they were welcomed with open hands by other Africans in accordance with the principle of teranga. According to narratives collected in the area, when the plague ultimately hit the multi-secular settlement of Dialaw in the outskirt of Dakar, the local African populations split and reorganized themselves into small-scale settlements 100-500 $\mathrm{m}$ distant from one another as a social distancing measure (Thiaw et al. 2018). Subsequent resettlement shows a movement toward the Atlantic coast, but populations maintained affective and symbolic relations with one another as well as with the earlier site of Dialaw. There still stands a baobab tree in Dialaw where all newborns, descendants of the mythical Thialaw Sene, the founder of the town, must come for life protection against all sorts of harms. Sites recorded in the area show great homogeneity in the material assemblages despite ethnic diversity. Likewise, the material assemblages associated with post- 1500 short-term settlements across northern Senegambia display the same kind of homogeneity. Although diseases and epidemics might not be the sole causes of site abandonment, settlement dynamics conform to the principles of a teranga aesthetic in that it instructs people to maintain social bonds and mutual assistance at times of disaster and uncertainty. The community-building approach of teranga and its practices of resilience constitute the building blocks of Senegalese culture. It is a heritage that Senegal (and indeed many other parts of Africa) can share with the rest of the world in crisis management.

\section{Conclusion}

Racism and racialization have their deep roots in the European imagination, especially beginning with the eighteenth-century Enlightenment (Curran 2011; Quijano 2007). It was built upon the negation of the humanity of non-European others. The dehumanization of black bodies in the context of the Atlantic slave trade and colonization went hand in hand with the European exploitation of Africa's human and natural resources. To attain and maintain this exploited relationship with Africa, Europe deployed complex strategies that were based on Eurocentric knowledge production. The results have been ecological and natural disasters with major political and socioeconomic consequences. These disasters are the precursors of the Anthropocene curse today (e.g., pollution, global warming, plundering of resources, overconsumption, environmental degradation, etc.). The COVID-19 pandemic has exposed the 
vulnerability of coloniality and challenged its hegemonic pretensions (see also Chakrabarty 2000), but it also calls attention to teranga aesthetic as a decolonial praxis (Rivera-Santana 2019). This is one area where we can start our search for decolonial epistemology in African archaeology and about crisis management in general.

\section{References}

Altschul, J., Thiaw, I., \& Wait, G. (Eds.). (2016). A slave who would be king: Oral tradition and archaeology of the recent past in the Upper Senegal River Basin. Oxford: Archaeopress.

Bigon, L. (2012). A history of urban planning and infectious diseases: Colonial Senegal in the early twentieth century. Urban Studies Research, 2012, 589758. https://doi. org/10.1155/2012/589758.

Blakey, M. L., \& Rankin-Hill, L. M. (Eds.). (2009). The New York African Burial Ground: Unearthing the African presence in colonial New York, vol. 1 (Skeletal biology of the New York African Burial Ground). Washington, DC: Howard University Press.

Canos-Donay, S. (2016). Territories, fortresses, and shifting towns: Archaeological landscapes of the Upper Casamance (Senegal), 7 th-19 ${ }^{\text {th }}$ centuries. Ph.D. thesis. University College of London.

Chakrabarty, D. (2000). Provincializing Europe: Postcolonial thought and historical difference. New Jersey: Princeton University Press.

Curran, A. S. (2011). The anatomy of Blackness: The science of slavery in the Age of Enlightenment. Baltimore: Johns Hopkins University Press.

Foucault, M. (1975). Surveiller et punir: Naissance de la prison. Paris: Gallimard.

France 24. (2020a). Tester des vaccins en Afrique. Tollé et excuses après une interview polémique. https://www.france 24 . $\mathrm{com} / \mathrm{fr} / 20200403$-tester-des-vaccins-en-afrique-toll\%C3 $\%$ A9-et-excuses-apr\%C3\%A8s-une-interview-pol\%C3\%A9 mique. Accessed 18 June 2020.

France 24. (2020b). L'Entretien. Antonio Guterres: avec le coronavirus, on risque des millions de morts en Afrique. https://www.france24.com/fr/europe/20200327-coronavirusen-direct-entretien-avec-antonio-guterres-secr\%C3\%A9 taire-g\%C3\%A9n\%C3\%A9ral-de-1-onu. Accessed 18 June 2020.

Gueye, N. S. (1998). Poteries et Peuplements de la Moyenne vallée du fleuve Sénégal du XVIe au XXe siècle: Approches ethnoarchéologique, archéologique et ethnohistorique. Ph.D. thesis, Laboratoire de Préhistoire et de Technologie, Maison de l'Archéologie et de l'Ethnologie René Ginouvès, université de Paris X- Nanterre France.
Maillard, M. (2020). Covid-19: Médias et réseaux sociaux africains mettent en cause un virus venu d'ailleurs. Le Monde Afrique, 06 mars 2020; https://www.lemonde. fr/afrique/article/2020/03/06/covid-19-medias-et-reseauxsociaux-africains-mettent-en-cause-un-virus-venu-dailleurs_6032116_3212.html. Accessed 18 March 2020.

Mantelin, F. (2020). Le Covid-19 vu par les experts du Quai D'Orsay: "L'effet pangolin", une note confidentielle sur la crise africaine qui vient. Le monde diplomatique; les blogs du "Diplo", mots d'Afrique. https://blog.mondediplo.net/1effet-pangolin-une-note-confidentielle-sur-la. Accessed 18 June 2020.

Quijano, A. (2007). «Race » et colonialité du pouvoir, Mouvements, 2007/3(51):111-118. https://doi.org/10.3917 /mouv.051.0111. URL : https://www.cairn.info/revuemouvements-2007-3-page-111.htm). Accessed 24 March 2020.

Richard, F. G. (2019). Reluctant landscapes. historical anthropologies of political experience in Siin, Senegal. Chicago: The University of Chicago Press.

Riley, E. J. (2016). Terànga and the art of hospitality: Engendering the nation, politics, and religion in Dakar, Senegal. Ph.D. thesis, Department of Anthropology, Michigan State University.

Rivera-Santana, C. (2019). Aesthetics of disaster as decolonial aesthetics: Making sense of the effects of Hurricane María through Puerto Rican contemporary art. Cultural Studies, 34(3), 341362. https://doi.org/10.1080/09502386.2019.1607519.

Sall, M. (2020). Déclration d'état d'urgence dans la cadre de la lute contre la maladie à coronavirus Covid 19. Presidential address on March 23, 2020. Présidence du Sénégal Actualités. http:/www.presidence.sn/actualites/declarationdetat-durgence-dans-le-cadre-de-la-lutte-contre-la-maladiea-coronavirus-covid-19_1996. Accessed on March 24, 2020.

Thiaw, I. (1999) Archaeological investigations of long-term culture change in the Lower Falemme (Upper Senegal Region), A.D. 500-1900. Ph.D. dissertation. Rice University.

Thiaw, I. (2012). Atlantic impact on Inland Senegambia: French penetration and African initiatives in eighteenth-nineteenth centuries Gajaaga and Bundu. In J. C. Monroe \& A. Ogundiran (Eds.), Power and landscape in Atlantic West Africa: Archaeological perspectives (pp. 49-77). New York: Cambridge University Press.

Thiaw, I, Ly, M. \& Baldé, D. (2018). New multi-use port of Dakar: Archaeology and cultural heritage studies. In Culture Heritage Report in collaboration with AECOM. IFAN, Dakar.

Thilmans, G. and Ravisé, A. (1980). Protohistoire du Sénégal. Recherches archéologiques, Tome 2, Sinthiou Bara et les sites du Fleuve. Dakar: Mémoires de l'Institut Fondamental d'Afrique Noire, $\mathrm{n}^{\circ} 91$.

Publisher's Note Springer Nature remains neutral with regard to jurisdictional claims in published maps and institutional affiliations. 